\title{
The Role of the Danish Language in Iceland
}

\author{
Auður Hauksdóttir (Reykjavík)
}

\begin{abstract}
Due to the long-standing relationship between Denmark and Iceland, the Danish language has played a significant role in Iceland for a long time. With urbanisation in the 19th century, a relatively high number of Danes settled in Reykjavík and Danish language and culture which was highly different from the traditional Icelandic rural culture became predominant in the city. With a growing national consciousness, the use of Danish and Danish loanwords came to be regarded as a threat to the mother tongue. However, greater independence gradually led to more balanced attitudes.

Knowledge of Danish was a key to education, as many Icelanders sought education of different types in Denmark. Danish was taught as a foreign language in Icelandic schools. Icelandic was the language of instruction in all subjects, although some of the textbooks were in Danish. The relationship with Denmark and the other Scandinavian countries remains close. Danish is still a compulsory subject in Icelandic primary and grammar schools and, nowadays, provides Icelanders with a key to understanding and using the rest of the Scandinavian languages.
\end{abstract}

\section{$1 \quad$ Introduction}

In an article from 1972 Haugen defines the concept 'Ecology of Language' as "the study of interactions between any given language and its environment" and states that the "true environment of a language is the society that uses it as one of its codes". According to Haugen, language only exists in the minds of its users and:

it only functions in relating these users to one another and to nature, i. e. their social and natural environment. Part of its ecology is therefore psychological: its interaction with other languages in the minds of bi- and multilingual speakers. Another part of its ecology is sociological: its interaction with the society in which it functions as a medium of communication.

(Haugen 1972: 325)

For about 560 years Denmark and Iceland shared a common history which began in 1383, when Norway, Iceland and Denmark were united, and ended in 1944, when Iceland became a republic. During the long period of time when Iceland was a part of the Kingdom of Denmark, the two countries had direct and indirect contact in various ways and Danish served as the language of communication in different contexts. This article focuses on the role of the Danish language in Iceland in a historical context. Consequently, the focus is primarily on the aspect of the ecology of language which Haugen calls 'sociological', namely 'its interaction 
with the society in which it functions as a medium of communication", as quoted above. In order to establish this role in view of Haugen's theories, it is important to determine the Icelanders' contact with Danish and the status and role of the Danish language in Iceland, i. e. when and how Danish came to be spoken or used in Iceland and for what purposes the Icelanders used it to communicate. When investigating the cohabitation of languages in the past, the perspective is limited by the written sources available. The sources often refer indirectly to the topic, which makes in inevitable to fill the gaps, interpret and make conjectures on the language use situation. There are numerous external conditions that can affect the evolution of language contact, e. g. the influence of ideological currents from the outside and sociological and political changes. The strengthening of royal power and increased centralisation in Denmark can serve as an example here, since this led to more extensive and diverse contact between Danish and Icelandic officials, with Danish as the language of communication. The reformation encouraged the use of the mother tongue, both in Denmark and in Iceland, and so did the ideas of national identity and the significance of the mother tongue when they gained support. However, it is worth bearing in mind that the promotion of the mother tongue in Denmark encouraged the Icelanders' use of Danish. On the other hand, the tradition of writing and practising literature in Iceland, together with the isolation and sparse population of the country, created an environment for the Icelandic language to prosper.

The following sections focus on some central aspects regarding the status and function of the Danish language in Iceland during the long-term union of the two countries. The primary focus will be on the circumstances that especially determined the Icelanders' use of Danish and their attitude towards the Danish language. In a short article like this, it is however only possible to briefly outline this complex history and the circumstances that caused language contact.

\section{Theories on language contact}

Since this is a diachronic study, it is essential to provide information that can cast light on the historical relationship of the two languages as well as their nature and role, as theories on language contact presume that influence from one language to another, e.g. on the vocabulary:

depends on extralinguistic factors such as the duration and intensity of cultural contact, the roles and status of the participating languages, language attitudes, and the degree of institutional support enjoyed by the languages (e. g. the presence of literacy).

(Matras 2009: 154)

As mentioned above, the Icelandic was a written language and documents from medieval times show how the language was used as well as its relationship to other languages. These documents are, for instance, translations into Icelandic and texts in Icelandic containing neologisms and loanwords from other languages. In her book Language Change Aitchison discusses how language change happens, when it happens, why it happens and who initiates it and other possible reasons for its occurrence (cf. Aitchison 2013: vii, 7). In theories on language change, e. g. regarding borrowings from a donor language into a recipient language, the importance of language contact is often mentioned. There may be many different reasons 
for language changes, such as borrowing words from other languages, but the degree of borrowing is considered to be dependent on the extent of exposure to the contact language (cf. Matras 2009: 153). According to Matras, the two most frequently cited motivations for borrowing are "gaps in the structural inventory of the recipient language, and the prestige enjoyed by the donor language" (Matras 2009: 149). Aitchison (2013: 153) also indicates the notion of need as a reason for words being borrowed from a foreign language, which can be explained as sociolinguistic causes of language change. As regards the hypothesis of filling a "gap", it is assumed that a bilingual or semi-bilingual speaker notices that the donor language possesses expressive means that the recipient language does not have. Typical "gap"-fillers are so-called "cultural loans" that often refer to new social activities, community functions, institutions and innovations, whereas the "prestige" hypothesis assumes that the speakers imitate elements of the speech of a socially more powerful, dominant community in order to gain approval and social status. Unlike cultural loans, "prestige" loans often have parallel expressions in the recipient language. However, these parallel expressions are not necessarily full equivalents in the pragmatic sense, as they may lack a special conversational effect and connotation that is evoked by the loanword (cf. Matras 2009: 150). In this context, the social and class-related circumstances in which the language is used can be of significance. Both the "gap-fillers" and the "prestige" loans can enrich the lexical inventory of the recipient language, but they can also replace words that already exist in the language. The notion of "prestige" can encourage lexical borrowing when, for instance, the donor language is the language of a politically powerful social elite or of a nation that has a dominant position because of its wealth or power. Structural similarities and differences (congruence) among the languages concerned also play an important role, as is the case with Danish and Icelandic, both being Germanic languages and closely related. Kühl, who has examined the influence of Danish in the Faroe Islands (cf. Kühl 2015) and Norway and elsewhere, points out that unstable language contact typically leads to transfer of lexemes and meaning, whereas more intensive contact results in language change within the whole structure of the language (cf. Kühl 2014: 34).

With regard to the role of Danish in Iceland, it is important to make a distinction between, on the one hand, Danish as a foreign language and the importance of knowledge of Danish for Icelanders, and, on the other hand, the influence of Danish on Icelandic. By definition, however, these roles can be interchanged, a relatively common knowledge of Danish as a foreign language could encourage borrowing from its vocabulary, or many Danish loanwords in Icelandic could reinforce the knowledge of Danish or make it more feasible to learn the language. Of course the opposite could also happen, i. e. many loanwords in the native language can cause a negative attitude or dislike for the foreign language and reduce the motivation for learning it.

In the following sections the extralinguistic factors that were important for the status and role of Danish in Iceland will be discussed. The cohabitation of Danish and Icelandic will also be examined with regard to the following questions:

1. What political, social and cultural circumstances promoted the use of Danish and encouraged Icelanders to learn the language? 
2. How did ideas of nationality in the $18^{\text {th }}$ and $19^{\text {th }}$ centuries influence the attitudes of Icelanders and Danes to Danish and Icelandic?

3. What was the status of Danish in Icelandic schools and what is it now?

In addition to outlining the historical circumstances that primarily created conditions for language contact, sources will be mentioned that can cast light on the Icelanders' knowledge of Danish and their attitudes towards the language and its importance. Examples will be given about traces of Danish in Icelandic society and how Danish left its mark on the Icelandic language by way of loanwords. Finally, the study and teaching of Danish as a foreign language in Icelandic schools will be discussed.

\section{From Bergen to Copenhagen}

The Icelanders, alone among the Nordic and Germanic peoples, have detailed historical records of their origin as a nation (cf. Benediktsson 1964: 29). Most Icelanders originally came from Norway's west coast and therefore brought a Norwegian immigrant language to their new country. Despite the fact that the Icelandic and Norwegian languages developed in two different directions early on, it is presumed that the differences between the languages only became noticeable in the $14^{\text {th }}$ century and onwards (cf. Benediktsson 1964: 27).

From the time of the settlement in the late $9^{\text {th }}$ century the inhabitants of Iceland were a relatively homogeneous people whose mother tongue was Icelandic. The Icelanders possessed a rich tradition of storytelling and wrote literature and other texts in Icelandic. From the beginning of the settlement, the Icelanders had a close and multifaceted contact with Norway. From the introduction of Christianity around year 1000, there was a close connection to the Norwegian church and it was strengthened further by the establishment of the Archdiocese of Trondheim in 1152-53, to which the Icelandic church belonged.

Iceland came under Danish rule in 1383, when the Icelanders swore allegiance to King Olaf IV, son of King Håkon VI and Queen Margareth I (cf. Porsteinsson/Grímsdóttir 1989: 245). Denmark and Norway were united under one king in 1380 and Iceland became part of the new enlarged kingdom. Initially, the contact with Denmark was not close, but gradually the situation changed. In the $14^{\text {th }}$ century, Bergen was the centre of Iceland's administration and the country's secular capital. Bergen kept this status until the kingdom moved the administration to Copenhagen, the future capital of Denmark. Copenhagen gradually acquired the same status Bergen formerly had (cf. Porsteinsson/Grímsdóttir 1989: 176-177). There are several examples of texts from around 1430 onwards, such as special licenses, royal orders and laws issued in Copenhagen, regarding Iceland and Icelandic relations. From this time on, the Icelanders also began to travel to the capital to tend to business with the king and his officials, whereby Danish gradually became important for Icelanders as a key to communication with Danes. The contact was nevertheless limited and sources show that other languages than Danish were often used, especially Latin and German.

With increased contact with Denmark, the use of Danish was encouraged in Iceland. By all accounts, communication between Icelanders and Danes was more difficult than it was between Icelanders and Norwegians. Compared to Norwegian, Danish was very different from Icelandic and direct contact between the two countries was limited until the end of the 
$15^{\text {th }}$ century. Nevertheless, it is worth bearing in mind that Icelandic and Danish are closely related languages with many similarities, especially regarding the basic vocabulary. During the first centuries of the Danish-Icelandic relationship, the two languages were not as different as they subsequently became. Nevertheless, sources show that the Icelanders could not understand or speak Danish without difficulty and therefore had to make an effort to learn the language. So, how did they learn Danish and for what purpose? A foreign language can be learned directly from speech, i. e. by communicating orally in the language, but learning Danish by that method would have required an association with the Danes. Another way for Icelanders to learn Danish was to read the language, which required access to reading material in Danish. Language contact was a necessary condition for them to learn Danish and the nature and extent of this language contact determined the kind of language skills they learned. The question is therefore, what kind of contact did the Icelanders have with the Danes and for what purpose did they need or want to use their language skills? What circumstances shaped the role of Danish in Iceland, the language of the ruling nation, and its cohabitation with Icelandic, the mother tongue of the Icelanders? And how did the ideological currents from the outside, such as theories on nationality and identity, affect the Icelanders' attitude towards Danish and their own mother tongue, Icelandic?

\section{$4 \quad$ The Reformation}

Following the Reformation, the Norwegian council was abolished and Icelandic matters were brought before the Danish council and the Danish king. The Reformation, which was imposed in Iceland in 1550, marked enormous changes in the relations with Denmark. Contact with the Archdiocese of Trondheim ceased and the Icelandic church came under the chancery in Copenhagen led by the king and the Diocese of Zealand. Here the Icelandic bishops were consecrated to their office until the end of the $19^{\text {th }}$ century. In 1584 , the first complete translation of the Bible into Icelandic was published and a few years later an Icelandic translation of hymns came out. The Icelandic translation of the Bible had a decisive effect on the evolution of the language. Translation of the Bible meant that the language of the church was Icelandic at times when the church had great influence in society and in the instruction of children and youth for confirmation. The Reformation also called for extensive translations of clerical texts that were originally written in Danish or translated into Danish from Latin or German. The Reformation therefore had a significant influence on the use of Icelandic and Danish in Iceland. In this context, it is worth pointing out how different the situation was in the Faroe Islands and Norway, where the Bible of Christian III was introduced shortly after the Reformation and as a result, the influence of Danish was strong. A complete translation of the Bible into Faroese was not published until 1949 and a book of Faroese hymns came out in 1961 (cf. Jacobsen et al. 2001: 6). In 1845, Danish was introduced as a language of instruction in the Faroe Islands (cf. Kühl 2014: 40), whereas the language of instruction in Iceland was Icelandic. In Norway, a complete translation of the Bible into standard Norwegian came out after the mid-19 $9^{\text {th }}$ century, and in 1921 a complete Biblical translation came out in New Norwegian, followed in 1925 by a book of hymns in New Norwegian (cf. Almenningen et al. 1992: 124). On the other hand, the significant clerical and societal changes following the Reformation in Iceland meant that more Icelanders were now confronted with Danish documents concerning Icelandic circumstances. As a result, many Icelanders had to learn to

ISSN 1615-3014 
read Danish. The changes in the leadership of the church created a closer collaboration between the Icelandic and the Danish church as well as a closer contact between the clerical and the secular power. Thereby bishops, principals and priests needed to communicate with each other, as did the clerical leaders and the representatives of the royal power. These changes and the increasing contact with the Danish language that they provoked, had a strong influence on the Icelandic tongue. Westergård-Nielsen's research (1946: LXXXI-LXXXVII) on loanwords in written Icelandic in the $16^{\text {th }}$ century has shown that extensive translations of clerical texts in connection with the Reformation, and the increased use of Danish texts, had a considerable influence on the Icelandic language, especially the vocabulary, as is shown by the many examples of Danicisms as well as loanwords from German that entered Icelandic via Danish. Everything seems to indicate that cultural loans played an important part in the process (cf. Matras 2009: 150).

After the Reformation, a growing number of Icelanders were educated in Copenhagen where they enjoyed special privileges at the Regensen residential college from 1579. Those who were educated at the University of Copenhagen often got the highest offices available to Icelanders and there are many examples that show that contact with Danes continued after their return to Iceland. These social circumstances enhanced the prestige of Danish and Danish proficiency. Because of the dominance of Latin at the university and in the scholarly community, Danish did not seem to play a significant role in the educational system in Denmark. However, this was only the case until the middle of the $18^{\text {th }}$ century, when it slowly came to replace Latin as the language of instruction (cf. Feldbæk 1982: 236-237; Hauksdóttir 2013: 76). Nevertheless, studying in Denmark and living in a Danish-speaking society must have required proficiency and communication in Danish to some degree.

\section{$5 \quad$ Danish and the administration}

Following the Reformation, the king's economic interests in Iceland increased, which enhanced the relations with Denmark as well as Danish influence in Iceland. It is, however, important to bear in mind that Icelandic laws were valid in Iceland and most officials were Icelandic until after the Reformation, which was the beginning of an era marked by the rule of Danish officials. Until 1683, the Danish authorities sent a governor who was the king's supreme representative in Iceland. In the period 1515-1683, 20 out of the 31 governors were Danish, while others were German, Norwegian or Icelandic (cf. Porláksson 2003: 28). However, most governors only occupied the office for a short period of time and some of them only stayed in Iceland briefly during the summer. Nonetheless, these changes encouraged the use of Danish since the central administration was in Denmark and the highest officials were Danish. The Royal Court of Law in Copenhagen was the highest court until 1661 when Denmark's Supreme Court was established. Legal documents submitted to the Supreme Court had to be translated into Danish, which was a task only those few that had advanced command of Danish were capable of performing. With the introduction of the trading monopoly in 1602, all trade was passed into Danish hands, which further strengthened the royal power and encouraged communication in Danish. The trading with Danish merchants in Iceland increased the language contact and required direct communication between Danes and many Icelanders. This is likely to have promoted the knowledge of 
Danish and increased the use of Danish loanwords, e. g. when the need arose to name new products or commodities unknown in Iceland.

In 1662, the Icelanders swore allegiance to King Frederick III as the absolute monarch of the kingdom. This resulted in radical changes in the governance of the country. Iceland now became a diocese county under the Danish absolute monarchy. Copenhagen became the centre for the legislative authority, the Office of Supreme Ombudsman and Denmark's Supreme Court. The king and his officials in Copenhagen took over many affairs. In the years 16831688 there were significant changes in the country's administration and new offices were introduced. The top offices, those of the prefect and the bailiff, were attended to by Danes. Since the Danish officials lacked knowledge of Icelandic the Danish language played a more significant role in Iceland than it had done before. The men of law and bishops, who were Icelandic, had to write reports in Danish about all secular and clerical officials and their functions. However, no changes were made in the local administration. The sheriffs, most of whom were Icelandic and educated in Iceland, were in charge of reinforcing the administrative power and had to send reports to the prefect about conditions in their district every year (cf. Porsteinsson 1985: 173). When a Danish law degree was introduced in 1736, it was made mandatory that the sheriffs were graduates in law from the University of Copenhagen and in the $18^{\text {th }}$ century, Danish law was increasingly applied alongside the ancient Icelandic law. This affected the language used by the Icelandic officials, both regarding borrowings from Danish and the syntax, e. g. the bureaucratic gobbledygook of German origin (d. kancellistil) (cf. Ottósson 1990: 26). New rules were implemented for trading in an effort to adjust to the Icelandic administration. The Icelandic harbours were let on lease in sets of two for six years at a time and the country was divided into trading districts (cf. Porsteinsson 1985: 181). These changes in the governance of the country meant that Danes and Icelanders had to solve more tasks in collaboration, which called for communication in Danish.

\section{Use of the mother tongue in Denmark}

With a growing national consciousness in Denmark in the $18^{\text {th }}$ and $19^{\text {th }}$ centuries, the Danish language gained strength in all areas of the Danish kingdom, especially within the educational system. A growing number of printed material was published in the $19^{\text {th }}$ century, particularly of textbooks and didactic texts, newspapers, periodicals and literature, both Danish and foreign literature in Danish translations. The extended use of Danish in Denmark had a great impact in Iceland (cf. Hauksdóttir 2011: 19-21). On the one hand, because of increased language contact and, on the other hand, because Icelanders in Copenhagen became acquainted with and adopted ideas of nationality and the importance of the mother tongue (cf. Hauksdóttir 2001: 22-25; 2013: 76-82). As the use of Danish became extended in Denmark, Danish textbooks came to be used more extensively in the Latin grammar school in Iceland, which required reading skills in Danish. Danish replaced Latin at the University of Copenhagen, so when it came to admission to the university, Icelandic students no longer were on an equal footing with the Danish ones as they had been when Latin was the language of instruction and exams. In order to satisfy the increased need for knowledge of Danish, instruction of Danish was reinforced in the Latin grammar School in Iceland (cf. Hauksdóttir 
2014: 29-34). In the $19^{\text {th }}$ century, secular contemporary literature in Icelandic was scarce, as were media such as periodicals and newspapers. It was not until the middle of the $19^{\text {th }}$ century that the first Icelandic news magazines came into existence. Therefore, Danish reading material was in high demand in Iceland, not only literature written in Danish or translated into Danish, but also newspapers and periodicals. Danish and Icelandic resemble each other mainly in writing, and as a result the Icelanders' easiest access to Danish was through the written language. Because of the significant motivation for reading secular texts in Danish, many Icelanders taught themselves to read the language (cf. Hauksdóttir 2011: 15-23). The Icelanders' acquaintance with Danish secular contemporary texts about new fields of knowledge pushed the elasticity of the language and documents show that a great number of loanwords characterised the Icelandic language in the $19^{\text {th }}$ century.

However, the Icelanders gradually began to question the Danish rule. Ideas of democratic rights were brought to Iceland by Icelandic students and scholars in Copenhagen. In Copenhagen, the Icelandic diaspora was also aware of the ideas about the role of the mother tongue in the awakening of a national identity. One of the aspects of the national consciousness in Denmark was the criticism made by scholars on German influence and loanwords in Danish (cf. Skautrup 1968: 143-153). In Germany, similar criticism was directed against French influence (cf. Jones 1999: 25-57), and later Danish influence in Norway also came in for criticism (cf. Haugen 1966: 29). No doubt the Icelandic scholars detected similarities between the position of the German language in Denmark and that of the Danish language in Iceland. In this context it is worth calling attention to the fact that the interest of Danish scholars in Icelandic, and that of Rasmus Rask (cf. Rask 1811) in particular, also reinforced linguistic consciousness and love for the mother tongue among Icelanders. In addition, it is worth bearing in mind that Old Icelandic literature became important for Danish nation building and several Danish purists saw Icelandic as an ideal language, which contributed to the awakening of Icelandic national consciousness (Hauksdóttir 2013: 69-70, 75-81). The interest of Danish scholars in Old Icelandic literature and the Icelandic language probably strengthened Icelandic national consciousness and self-esteem. The use of the Danish language began to be criticised, especially the use of Danicisms when speaking and writing Icelandic. By now, interest in language purism thrived in society.

\section{Urbanisation - Reykjavík and the Danish language}

By the end of the $18^{\text {th }}$ century and the beginning of $19^{\text {th }}$, the first signs of urbanisation appeared in Iceland. Changes in administrative, commercial and demographic conditions in particular, came to enhance the development of Reykjavík as the country's future capital. At that time, a significant number of Danish merchants and tradesmen lived with their families in Reykjavík and its neighbourhood, as well as several Icelandic and Danish officials. Loanwords related to trade still bear witness to the influence of the Danish merchants and the contact Icelanders had with their language, e. g. the following: prókúra (d. prokura) 'authority to sign for a company', nettó (d. netto) 'net' and brúttó (d. brutto) 'gross'. Because of the specific combination and power of these groups, a foundation was created for an environment where Danish language and culture that was very different from the traditional Icelandic rural culture became predominant. The Danish-Icelandic elite thereby became trend-setting for 
other Icelanders. Because of the influence and power of the Danes and Danish-speaking Icelanders, it was seen as prestigious to be able to read and speak Danish, which encouraged the use of the language as well as the use of Danicisms in Icelandic (cf. Matas' theories above). Other towns were gradually established around the country where a similar development occurred, although on a smaller scale. The towns Ísafjörður in the West Fjords, Akureyri in the North of Iceland and Eskifjörður and later Seyðisfjörður in the East are worth mentioning in this context. However, it is important to bear in mind that at this time Iceland was primarily a rural society and Reykjavík was not a major town. At the beginning of the $19^{\text {th }}$ century, or in 1801 to be more specific, there were 47,812 people living in Iceland, and 307 of them resided in Reykjavík. In 1850 Reykjavík's inhabitants counted 1,149 of a total population 60,416 and in 1901, there were 78,641 people living in Iceland, 6,682 of whom lived in Reykjavík (cf. Jónsson/Magnússon 1997: 56-59, 66-67). Other changes also came with the urbanisation and the new circumstances called for new words. Danish houses differed from the Icelandic ones and so did the interior decoration and furnishing, as can be seen by the following loanwords: altan (d. altan) 'balcony', bíslag (d. bislag) 'porch', mubla (d. møbel) 'furniture', lenistóll (d. loenestol) 'armchair', gardína (d. gardin) 'curtain'. There was also a significant difference between the Danish and the Icelandic way of dressing. The Danes wore European clothes as did the Icelanders who had been abroad while the Icelandic villagers and peasants were dressed in traditional Icelandic clothes. The Icelanders who had lived in Denmark wanted to keep step with the foreign fashion, which also encouraged the use of Danish words. Many sources show that the European fashion was conceived as Danish and European clothing was introduced in Iceland by Danes, as witnessed by the following borrowings: kjóll (d. kjole) 'dress', blússa (d. bluse) 'blouse', sjal (d. sjal) 'shawl', slifsi (d. slips) 'tie' and slör (d. slør) 'veil'.

Danish lifestyle and entertainment also differed from that of the Icelanders. The Danes promoted the art scene by theatre productions in Danish. Tombolas and associated activities were also considered typical Danish activities, e.g. the loanwords konsert (d. koncert) 'concert', ball (d. bal) 'dance', basar (d. basar) 'bazaar', ópera (d. opera) 'opera', tombóla (d. tombola) 'tombola' and teater (d. teater) 'theatre'. Icelanders tended to find it fashionable to speak Danish and therefore often used Danish words and phrases concernig manners or customs that were considered Danish, such as adjö or adiu (d. adjø) 'good-bye', hufflegur/hupplegur (d. høflig) 'polite' and vertshús/verðshús/vershús (d. vortshus) 'pub'. Thereby, Danish achieved a symbolic function as the prestigious language of the elite which in turn encouraged the use of Danish. Sources even show that Danish was frequently used by Icelanders in situations where it was not required. These conditions encouraged the use of Danish and the use of Danicisms to a considerable extent, especially in areas where Danish influence was strongest (cf. Hauksdóttir 2011).

With urbanisation, a basis and need for specialisation in certain trades was created, such as crafts and nursing. Sometimes, trained craftsmen came from Denmark to work in Iceland for longer or shorter periods of time, and in other cases Icelanders travelled to Denmark to learn a trade. Icelanders' contact with Danes in Iceland and in Denmark encouraged the use of Danish loanwords in fields of work that were being introduced in Iceland. However, when examining Danish influence in Iceland, it is important to bear in mind that the use of Danish varied considerably from one time to another depending upon developments in Iceland and

ISSN 1615-3014 
influences from Denmark, but also upon the place of residence and social status of the Icelanders. There was an enormous difference, for instance, between the use of Danish in the towns and in the rural areas, where many people never or scarcely came into touch with the Danish language or culture, whereas contact with Danish in Reykjavík was an everyday occasion for several Icelanders.

\section{Danish as a foreign language in Icelandic Schools}

The Danish language also played a significant role regarding education. In the beginning of the $19^{\text {th }}$ century there was only one school in Iceland - the Latin grammar school at Bessastaðir - the successor of the Latin grammar schools at the two sees, located respectively in the North and in the South of the country. At the grammar school at Bessastaðir, Danish was included as one of the subjects and a large portion of the material in other subjects was also in Danish. Many youths travelled to Denmark to study and since Danish had replaced Latin as a language of instruction, Danish proficiency was a prerequisite for those who wanted to study at the University of Copenhagen. However, this was not without difficulty for the Icelandic students. The entrance examination called examen artium required some effort in particular. The entrance examination was in Danish and since most of the Icelandic students came from the countryside, where there was limited Danish influence and Danes were a rare sight, it was difficult for many of them to understand and speak Danish, although they could read the language easily and perhaps even express themselves in writing. For these reasons, it became a strategic issue to strengthen the instruction of Danish in Iceland.

In 1846, the grammar school was moved from Bessastaðir to Reykjavík and new rules were implemented. It was decided that Danish and Icelandic should be the school's principal subjects. Icelandic should be taught as the mother tongue while Danish should have the same status as German had in Danish schools, i. e. that of a foreign language. Despite the strengthening of the Danish instruction, spoken Danish was still problematic for many Icelanders since the traditional teaching methods mostly focused on reading and writing. The teaching was based on grammar and translation, the students mainly engaged in translating from Danish to Icelandic, learning grammar and vocabulary and writing style exercises that focused on difficult grammar rules and exceptions. The grammar and the translation exercises worked well when teaching grammar, reading, vocabulary and writing, but were unsuitable for teaching spoken Danish. It is worth noticing that only a few teachers of Danish were qualified for teaching the language. As was the case at the grammar school at Bessastaðir, a large part of the material in other subjects was also in Danish.

During the second half of the $19^{\text {th }}$ century, primary schools were established, especially in the more densely populated areas, i. e. in the towns and near important trading stations. In most of these schools, Danish was among the subjects taught. By the end of the $19^{\text {th }}$ century, other types of schools were established such as secondary schools, agricultural schools, women's colleges and later on navigation schools and secondary modern schools. At these schools, Danish was taught as a foreign language and several of the textbooks in other subjects were in Danish (cf. Hauksdóttir 2001: 34-38). Many persons travelled to Denmark to seek further academic education, or to learn a trade or get practical training of different types, and Danish proficiency was crucial in this connection. 


\section{$9 \quad$ Attitudes towards Danish and the teaching of Danish}

As mentioned above, the use of the Danish language had a symbolic function in society because it indicated a membership of the Danish-Icelandic elite, which was better off than the other members of society. In the $19^{\text {th }}$ century, not many Danes had a permanent residence in Iceland. In the period 1860-1870, approximately 100 foreign nationals resided in Iceland, but in 1880 the number dropped to 71 whereof 69 were Danish. In the following years, the number of Danes in Iceland grew and in 1901 there were 213 inhabitants of Danish origin, corresponding to approximately 2\% of the population in Iceland (cf. Ellenberger 2015: 38). This had a significant impact since the Danes were an influential and powerful group, all of whom lived in the towns, the majority in Reykjavík. Many important Icelanders also lived in Reykjavík, they had studied in Denmark and some had Danish spouses. As a result, Danish influence grew stronger while the Icelandic demands for independency grew louder and criticism of the dominance of the Danish language intensified. The language in the towns, especially in Reykjavík, was considered degenerate and spoiled by Danish loanwords. The pure and clean Icelandic, which was spoken in the rural areas, became an ideal for language use because it had changed little and was the language of the sagas. Therefore, attitudes towards the Danish language became more negative. Speaking Danish was criticised especially and sometimes seen as an indication of subservience to the Danes, although the ability to read Danish, or even Norwegian or Swedish, was seen as important because it gave access to secular literature. In the meantime, the Icelanders very much needed to master the Danish language since knowledge of Danish was their key to education, career and entertainment.

The beginning of the century was thus marked by controversies between Icelanders and Danes. The Icelanders' struggle for independence created conflicts and emotions ran high. During this turbulent period, the Danish authorities tried to create an atmosphere of optimism by strengthening the contact with Iceland (cf. Hauksdóttir 2015: 164-178).

In 1907, the first Schools Act about general education was passed. A survey that had been carried out before, showed that several primary schools dispensed their teaching in Danish. This was criticised on the grounds that young children should obtain linguistic skills primarily in their mother tongue and that instruction in Danish had a negative impact on their ability in Icelandic. In the following period, teaching of young children in Danish was markedly reduced (cf. Hauksdóttir 2001: 127-139). Although the teaching of Danish was not mentioned in the first Schools Act from 1907, sources show that Danish was taught at several schools. However, it was not until the Schools Act of 1936 that it was stated that children should be taught foreign languages provided they were proficient in Icelandic. There is no doubt that foreign languages meant Danish in this context. At the country's only grammar school - the Reykjavík Grammar School - and later at new grammar schools, Danish was a compulsory subject. With the passing of a set of laws in 1946, one foreign language could be taught in the $6^{\text {th }}$ school year, provided the pupils were skilled in their own mother tongue. Furthermore, Danish was obligatory for pupils on the academic line in the upper grades of compulsory school.

In 1904, Iceland was granted Home Rule; in 1911 the University of Iceland was established and in 1918, Iceland became a sovereign state. Thereafter, the Icelandic Republic was 
founded in 1944. With greater independence, the administration moved to Reykjavík and fewer tasks called for collaboration between Icelanders and Danes. However, the relationship between the two countries remained close. Many Icelanders travelled to Denmark to study and Danish culture left its mark in the Icelandic community. Many Danes and Icelanders were connected through friendship and family ties. Danish culture continued to have influence in most areas of Icelandic society, for instance in the field of entertainment. From the beginning of the century, Danish theatre groups performed in Iceland from time to time and in 1906, the first cinema was founded in Reykjavík. Theatre and revues were highly influenced by Danish culture, as were films. Danish films were and still are very popular in Iceland. For several decades, films from other foreign countries were imported to Iceland via Denmark. For this reason, the foreign films often had Danish subtitles and the programmes used to be in Danish. Danish weekly magazines, periodicals and novels were widely popular and Donald Duck in Danish enjoyed huge success. All this contributed to the Danish proficiency of Icelanders (cf. Hauksdóttir 2015).

After the Second World War, a large number of young Danes immigrated to Iceland, such as artisans, nurses and workers. Thereby, a different kind of social groups came to Iceland from Denmark, and these groups settled all around the country, also in the rural areas (cf. Hauksdóttir/Jónsson/Skyum-Nielsen 2015).

In the $1970 \mathrm{~s}$, a comprehensive reform took place concerning the instruction of Danish in Icelandic schools. Danish teaching began at an earlier age and more emphasis was placed on spoken Danish. However, these changes did not have the expected results (cf. Hauksdóttir 2001: 159-189). In the same decade, the first medieval manuscripts, Iceland's finest national treasure, were returned to Iceland from Denmark, which greatly improved the relations between the two countries.

At the turn of the $21^{\text {st }}$ century, English replaced Danish as the first foreign language taught in Icelandic schools. Nevertheless, Danish is still a compulsory subject in grammar schools as well as in primary schools. Icelandic textbooks have replaced the Danish ones, and Danish language instruction now has the broader focus of providing Icelanders with a key to the rest of the Nordic languages.

\section{Conclusion}

Danish became an important language of communication for Icelanders when Copenhagen was made the administrative centre of the Danish-Norwegian kingdom. Following the Reformation, the need arose for Icelandic translations, as is indicated by the great number of loanwords that entered the language. The increased power of the king also encouraged the use of Danish in Iceland, especially in high administration and communication between officials. This was counterbalanced by the fact that Icelandic was a well-established written language, the Bible was translated by the end of the $16^{\text {th }}$ century and the Icelanders wrote literature in their mother tongue. In addition, Icelandic laws had been valid for a long time and the officials, such as priests and sheriffs, who had the closest contact with the general public, were Icelandic. Therefore, the status of Danish in Iceland was very different from what it was in the Faroe Islands and Norway where there was much more Danish influence. 
Growing national consciousness by the end of the $18^{\text {th }}$ century resulted in an increased interest in using Danish in Denmark, especially in schools. The use of Danish in the schools, the publication of Danish textbooks and books and periodicals on current affairs in Denmark, encouraged the use of the language in Iceland. Knowledge of Danish became a prerequisite for studying at the university and at other educational institutions. The instruction of Danish as a foreign language in Iceland was therefore reinforced in the grammar school and when new types of schools were established in the latter part of the $19^{\text {th }}$ century, Danish was among the subjects taught. Danish books, periodicals and weekly magazines became highly popular in Iceland and encouraged a large group of Icelanders to learn Danish. As a result of demographic changes new circumstances arose, and when new fields of knowledge were discovered there was need for new words in Icelandic. Because of the contact with Danish a large number of cultural and prestige loanwords entered into Icelandic from the Danish language.

Icelandic medieval literature played an important role in building Danish national identity and several Danish purists saw Icelandic as an ideal language, which contributed to the awakening of Icelandic national consciousness. A growing awareness about the importance of the mother tongue for Icelandic identity reinforced the position of the Icelandic language and provoked negative attitudes towards the use of Danish in an Icelandic context. In the meantime, knowledge of Danish became the Icelanders' key to education and a career.

With urbanisation in the $19^{\text {th }}$ century, elite groups were formed at the important trading stations, especially in Reykjavík, where influential Danes and Icelanders educated in Denmark had considerable power. Their lifestyle and their use of the Danish language distinguished them from the general public. For some time, this elite set the trend for others. Within this group, and among those who wanted to belong to it, it was regarded prestigious to speak Danish or use Danicisms when speaking Icelandic. With growing national consciousness and increased independence, the opposition towards Danish and its influence on Icelandic grew stronger. It was especially seen as undesirable to teach Danish to young children since it could have a negative effect on their use of the mother tongue. Sources show that Danish loanwords were frequent in Icelandic texts from the $19^{\text {th }}$ century, e. g. in letters, newspapers and periodicals.

As can be seen from the above, the influence of Danish was considerable for a length of time. However, the language contact in Iceland was in many ways different from what happened in the Faroe Islands and Norway, where the influence of Danish was much more extensive. In this context, possessing an Icelandic written language was of crucial importance, as well as was the Icelandic Bible, the Icelandic laws and Icelandic officials who had close contact with the general public. Sources show that many Icelanders did indeed learn to speak Danish when living in Denmark or by communicating with Danes in Iceland, but it is not clear how proficient they were in the language. Sources also show that many Icelanders were able to write Danish. Ability to read was however undoubtedly the skill mastered by the majority, as is witnessed by the number of Danish books the Icelanders possessed as well as by the number of sources that show that Icelanders read Danish for pleasure. The attitudes towards Danish and learning Danish were positive at the beginning and the use of Danish signalled membership of the Danish-Icelandic elite. With growing national consciousness, attitudes 
towards Danish turned more negative, especially regarding the use of Danish words in the Icelandic language. However, Danish is still an important subject in Icelandic schools, but now with a broader focus, namely to provide Icelanders with a key to the rest of the Nordic languages.

\section{References}

Aitchison, Jean (2013): Language Change: Progress or Decay? Cambridge: Cambridge University Press.

Almenningen, Ole et al. (eds.) (1992): Språk og samfunn gjennom tusen år. Ei norsk språkhistorie. Oslo: Universitetsforlaget.

Benediktsson, Hreinn (1964): „Íslenzkt mál að fornu og nýju. Fyrri hluti“. In: Halldórsson, Halldór (ed.): Paettir um islenzkt mál eftir nokkra íslenzka málfrceðinga. Reykjavík, Almenna Bókafélagið: 29-46.

Benediktsson, Hreinn (1964): „Upptök íslenzks máls“. In: Halldórsson, Halldór (ed.): Pcettir um islenzkt mál eftir nokkra íslenzka málfrceðinga. Reykjavík, Almenna Bókafélagið: 928.

Ellenberger, Íris (2015): „Danskere på Island i første halvdel af det 20. århundrede. Integration, transnationalisme og multikultur.“ In: Hauksdóttir, Auður/Jónsson, Guðmundur/Skyum-Nielsen, Erik (eds.): Gullfoss. Mødet mellem dansk og islandsk kultur i 1900-tallet. Copenhagen, Vandkunsten: 38-84.

Feldbæk, Ole (1982): Danmarks historie. Bd. 4: Tiden 1730-1814. Copenhagen: Gyldendal. Jónsson, Guðmundur/Magnússon, Magnús S. (eds.) (1997): Hagskinna. Icelandic Historical Statistics. Reykjavík: Hagstofa Íslands.

Haugen, Einar (1966): Language Conflict and Language Planning. The Case of modern Norwegian. Cambridge, Massachusetts: Harward University Press.

Haugen, Einar (1972): “The Ecology of Language". In: Dil, Anwar S. (ed.): The Ecology of Language. Essays by Einar Haugen. Standford, Standford University Press: 325-339.

Hauksdóttir, Auður (2001): Laererens strategier-elevernes dansk. Dansk som fremmedsprog $i$ Island. Copenhagen: Nordisk Ministerråd.

Hauksdóttir, Auður (2011): „Danske minder i Island. Om mødet mellem dansk og islandsk kultur“. Danske studier - tidsskrift for dansk sprog, studier og folkeminder: 5-49.

Hauksdóttir, Auður (2012): Dansk som fremmedsprog $i$ en akademisk kontekst: Om islcendinges behov for danskkundskaber under videreuddannelse i Danmark. Copenhagen: University of Copenhagen.

Hauksdóttir, Auður (2013): “Language and the Development of National Identity: Icelanders' attitudes to Danish in turbulent times". Kult 11. 'Made in Denmark'. Investigations of the dispersion of 'Danishness': 65-94.

Hauksdóttir, Auður (2014): „Um dönskukunnáttu Íslendinga á nítjándu öld“. Milli mála Tímarit um erlend tungumál og menningu 6: 13-42.

Hauksdóttir, Auður (2015): „Islændingenes møde med dansk sprog“. In: Hauksdóttir, Auður/Jónsson, Guðmundur/Skyum-Nielsen, Erik (eds.): Gullfoss. Mødet mellem dansk og islandsk kultur i 1900-tallet. Copenhagen, Vandkunsten: 164-222.

Hauksdóttir, Auður/Jónsson, Guðmundur/Skyum-Nielsen, Erik (2015): „Indledning. En anderledes historie om de to landes samkvem“. In: Hauksdóttir, Auður/Jónsson, 
Guðmundur/Skyum-Nielsen, Erik (eds.): Gullfoss. Mødet mellem dansk og islandsk kultur i 1900-tallet. Copenhagen, Vandkunsten: 21-37.

Jacobsen, Jógvan i Lón et al. (2001): Domoenetab og sprogpolitiske initiativer i foerøsk. Unpublished report for Den sprogpolitiske referencegruppe. Copenhagen: The Nordic Council of Ministers.

Jones, William Jervis (1999): Images of Language. Six Essays on German Attitudes to European Languages from 1500-1800. Amsterdam/Philadelphia: Benjamins.

Kühl, Karoline (2014): „Danske aflæggere i Nordeuropa: færødansk, sydslesvigdansk og bokmål““. Dansk Talesprog 14: 29-54.

Kühl, Karoline (2015): „Faroe Danish: An unknown variety“. In: Torgersen, Eyvind et al. (eds.): Language Variation - European Perspectives V. Selected Papers from the Seventh International Conference on Language Variation in Europe (ICLaVE 7). Amsterdam/Philadelphia, Benjamins: 157-169.

Matras, Yaron (2009): Language contact. Cambridge: Cambridge University Press.

Ottósson, Kjartan G. (1990): Íslensk málhreinsun. Sögulegt yfirlit. Reykjavík: Íslensk málnefnd.

Rask, Rasmus K. (1811): Vejledning til det islandske eller gamle nordiske Sprog. Copenhagen: Schubotheske.

Skautrup, Peter (1968): Det danske sprogs historie. Tredie bind. Copenhagen: Gyldendal.

Vikør, Lars S. (1993): The Nordic Languages: Their status and Interrelations. Oslo: Novus.

Westergård-Nielsen, Christian (1946): Låneordene i det 16. århundredes trykte islandske litteratur. Copenhagen: Munksgaard.

Porláksson, Helgi (2003): „Frá kirkjuvaldi til ríkisvalds“. In: Líndal, Sigurður (ed.): Saga Íslands VI. Reykjavík, Hið íslenzka bókmenntafélag og Sögufélag: 1-458.

Porsteinsson, Björn (in collaboration with Bergsteinn Jónsson and Helgi Skúli Kjartansson) (1985): Island. Copenhagen: Politikens.

Porsteinsson, Björn/Grímsdóttir, Guðrún Á. (1989): „Norska öldin“. With appendices by Sigurður Líndal. In: Líndal, Sigurður (ed.): Saga Íslands IV. Reykjavík, Hið íslenzka bókmenntafélag og Sögufélag: 59-258.

Porsteinsson, Björn/Grímsdóttir, Guðrún Á. (1990): „Enska öldin“. With appendices by Sigurður Líndal. In: Líndal, Sigurður (ed.): Saga Íslands $V$. Reykjavík: Hið íslenzka bókmenntafélag og Sögufélag: 1-216. 